\title{
NEWS FROM HEADQUARTERS
}

\section{Elections}

At its meeting on 5 and 6 December 1990, the Assembly of the International Committee of the Red Cross held elections with the following results:

- Mrs. Denise Bindschedler-Robert, who has reached the age limit for ICRC members, is leaving the Committee after 23 years of service. She was elected Honorary Member of the ICRC.

- Dr. Athos Gallino, who has also reached the age limit, is leaving the ICRC after 13 years of service. He was elected Honorary Member.

- For health reasons, Dr. Alain Rossier did not seek re-election to the Committee. He was elected Honorary Member.

- Mr. Hans Haug was re-elected Member of the ICRC for a third term, to end when he reaches the age limit at the end of 1991.

- Mrs. Renée Guisan was re-elected Member of the ICRC for a second four-year term.

- Mr. Cornelio Sommaruga was re-elected Member of the ICRC for a second four-year term. Mr. Sommaruga's mandate as President, which he received in 1987 , will come up for renewal at the end of 1991.

\section{Official visits to Headquarters}

Between October 1990 and the end of the year, the President of the ICRC together with members of the Committee and senior staff of the institution received the following visitors:

- Prince Hans Adam II and Princess Marie of Liechtenstein, on 18 October 1990. 
- General Chatichai Choonhavan, Prime Minister of the Kingdom of Thailand, on 19 October 1990.

- Dr. Sayid Mohammed Najibullah, President of the Republic of Afghanistan, on 22 November 1990.

- Mr. Vaclav Havel, President of the Czech and Slovak Federal Republic, on 23 November 1990.

Since October 1990, the President of the ICRC, Mr. Cornelio Sommaruga, has carried out missions to Italy, Denmark and Switzerland.

\section{Italy}

The ICRC President, accompanied by Mr. Francis Amar, deputy Delegate General for Europe and North America, and Mr. Jean-Luc Blondel, head of the Division for Principles and Relations with the Movement, took part in a meeting of National Society Presidents from the countries of the European Economic Community (EEC). The meeting was organized by the Italian Red Cross and held in Asolo, near Venice, from 8 to 11 October 1990.

The discussions focused on internal matters concerning EEC countries (civil defence, medical transports and blood transfusion) and on participants' relations with the EEC itself and with other National Societies. The participants reaffirmed their desire to contribute to the development of eastern European National Societies without, however, neglecting sister Societies in the Third World.

On 6 and 7 October, before proceeding to Asolo, the ICRC President went to Casale Monferrato, near Alessandria, to take part in a study programme organized by nursing volunteers from the Piedmont and Aosta Valley branches of the Italian Red Cross. He also gave a lecture on 15 October to a human rights seminar at the European University Institute in Florence. 